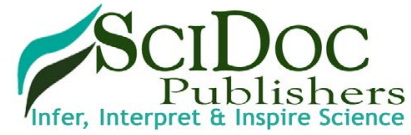

\section{Variation of Carbon Sequestration in Relation to Leaf Level RNA:DNA In Sundarban Mangrove, India}

Review Article

Majumder N, Chowdhury C, Jana TK*

Department of Marine Science, Calcutta University, Kolkata, India.

Abstract

Mangrove productivity varies in space and time depending on community structure, phenology, resource availability and salinity stress. In Indian Sundarbans, mangrove species with different growth rate sequester significant amount of carbon. This study reports the applicability of using leaf level RNA:DNA ratios for assessing intraspecific and interspecific differences in carbon sequestration of four mangrove species under field condition. It was observed that DNA concentration in mangrove leaves varied within a relatively narrow range, and higher variations in RNA could indicate its direct implication in protein synthesis, which in turn was strongly dependent on environmental condition such as nitrogen $(\mathrm{N})$ and phosphorus (P) availability and salinity stress. Leaf level RNA:DNA ratio in mangrove could be a good indicator of carbon sequestration and mangrove could maintain high carbon sequestration rate under nutrient limited condition through nutrient conservation strategies.

Keywords: Nucleic Acids; Growth Rate; Nutrients; Eco Stoichiometry; Salt Tolerant Plants.

\section{Introduction}

Mangroves dominate the majority of the world's tropical and subtropical coastlines, forming 15 million hectares of forest worldwide and accounting for $0.7 \%$ of the tropical forest area [22]. Mangroves are highly productive and known to fix (1.5-

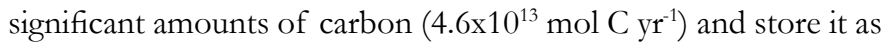
live biomass $\left(3 \times 10^{14} \mathrm{~mol} \mathrm{C}\right)[2,23,50]$. Changes in atmospheric $\mathrm{CO}_{2}$ concentration, climate, and sea level will lead to complex interactions affecting the structure and function of mangroves [35]. Although mangrove ecosystems are rich in carbon, they are often nutrient poor [31]. It is of interest to know how they maintain such high productivity under poor nutrient conditions. Nitrogen was found to limit growth of Avecennia marina in South Africa [37] and New Zealand [15]. Nitrogen is an essential component of all enzymes and phosphorus is vital for protein synthesis forming an essential component of RNA and DNA [17]. Salinity stress, that is, beyond appropriate salinity, either low or high, could affect the major physiological characteristics, such as photosynthesis and protein synthesis [14, 30, 54]. Laguncularia racemosa (L.) Gaertn. f. (Family: Combretaceae), also known as white mangrove, is found either in a river basin with high nutrient input or near a salt marsh, suffering from high soil salinity and low nutrient input in Sepetiba Bay (Rio de Janeiro, Brazil). Mangrove forests near salt marshes have been classified as dwarf forests, because they have abnormal growth. In spite of significant morphological dissimilarities, individuals of $L$. racemosa from salt marsh and riverside presented little genetic but abundant DNA methylation differentiation [28]. In trees, growth is an important variable in understanding responses to disturbances and environmental conditions such as resource availability, competition and stress [24].

The relative abundance of RNA in comparison with DNA in the cell has been used successfully to predict growth and nutritional state in a multitude of studies on a variety of organisms such as bacteria [27], phytoplankton [13]. Vrede et al., 2004 [51] showed interspecific differences in RNA relative to DNA content to explain differences in growth rate between bacteria or eukaryotes with faster growth rate relative to slow growing insects or molluscs. Few studies have been attempted to use RNA:DNA ratio as an indicator of interspecific variation in growth for plants. According to Growth Rate Hypothesis faster growing organisms should have more phosphorus content per unit biomass and Lovelock et al., 2007 [15] tested and supported the hypothesis

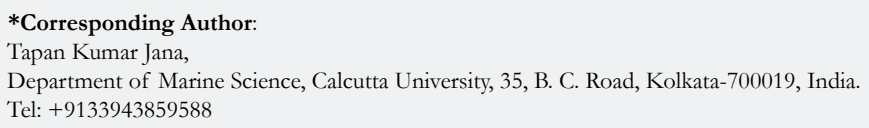

Copyright: Jana TK $^{\circ}$ 2016. This is an open-access article distributed under the terms of the Creative Commons Attribution License, which permits unrestricted use, distribution and reproduction in any medium, provided the original author and source are credited. 
for mangroves. Mangrove growth could depend on resource availability (nutrient) and stress (salinity) in sediment [9] and could be linked to mangrove leaf level RNA: DNA.

Ribulose $1 \cdot 5$-bisphosphate carboxylase/oxygenase (Rubisco), a key enzyme in photosynthesis and the most abundant leaf protein accounts [20,33] generally has a very high control coefficient over $\mathrm{CO}_{2}$ assimilation and is an enormous nitrogen sink, as it can take up to half of the total soluble nitrogen content. Interspecific differences in $\mathrm{CO}_{2}$ assimilation are unlikely to be associated with rubisco concentration, rather than the active DNA and RNA content. Suzuki et al., 2010 [49] observed Rubisco concentrations and nitrogen influx for its synthesis in fully developed matured leaves remained constant and suggested that low Rubisco protein turnover rate in Eucalyptus globulus leaves could lead to maintain Rubisco contents and photosynthetic activity. Noguchi et al., 2001 [39] suggested that low protein turnover rate could be advantageous in terms of energy cost to the maintenance of photosynthetic activity in woody plants. Intraspecific and interspecific differences in carbon sequestration are likely to be associated with transcription, rather than rubisco content. Since translation or protein synthesis is also related to growth and RNA is directly involved in protein synthesis, RNA:DNA ratio could be a measured indicator of carbon sequestration.

Indian Sundarban mangrove is known for its high productivity and acts as a sink for atmospheric $\mathrm{CO}_{2}$ [41]. Ray and others 2013 suggested that enhancement of productivity in response to future increases of atmospheric $\mathrm{CO}_{2}$ would require additional supplies of nutrients. The material costs of rapid carbon sequestration in terms of $\mathrm{P}$ demands for ribosomes (the site of protein synthesis) and $\mathrm{N}$ demands for the protein themselves under nutrient limitation could produce selective pressure to genome [1, 34].

The purpose of the present study was to examine the variability of the relationship between leaf-level RNA:DNA ratio and carbon sequestration by mangrove species under field condition such as resource availability ( $\mathrm{N}$ and $\mathrm{P}$ ) and salinity stress in the Indian Sundarban.

\section{Materials and Methods}

\section{Study sites and Mangrove Systems}

The study sites (Figure 1) are located in the Indian Sundarban, $\left(21^{\circ} 32 /\right.$ and $22^{\circ} 40 / \mathrm{N} ; 88^{\circ} 05 /$ and $\left.890 \mathrm{E}\right)$ at the estuarine phase of the River Ganges and comprise $9630 \mathrm{~km}^{2}$ (sprawling archipelago of 102 islands including 54 islands reclaimed for human settlement), out of which $4264 \mathrm{~km}^{2}$ is intertidal mangrove forest surrounded by $1781 \mathrm{~km}^{2}$ of water area. Climate in the region is characterized by the southwest monsoon (June-September), north east monsoon or post-monsoon (October-January) and pre-monsoon (February-May) and $70-80 \%$ of annual rain fall occurs during the summer monsoon (South west monsoon), resulting river discharge to increase from $900 \mathrm{~m}^{3} \mathrm{~s}^{-1}$ to 11,897 $\mathrm{m}^{3} \mathrm{~s}^{-1}[36]$. The large tidal range and extremely gentle shelves (1.2$4.0^{\circ}$ ) with muddy substrate make water current and tidal action quite appropriate for extensive mangrove occurrence. Avicennia alba, Avicennia marina, Aegialitis rotundifolia, Bruguiera gymnorrbiza are the pioneering mangroves. Mangrove plants rarely exceed $10 \mathrm{~m}$ height.

\section{Sample collection and methods}

Between June and December 2011, all measurements were made monthly and quadrates $(10 \times 10 \mathrm{~m})$ were selected randomly in west Sundarbans: Lothian Island North (Stn.1, four quadrates), Lothian Island South, Ecocamp (Stn.2, four quadrates).

Nutrients In The Sediment: Sediment samples in duplicate were collected from each sampling site (intertidal zone with mangrove vegetation) at low tide during three seasons (monsoon, post-monsoon and pre-monsoon). Undisturbed sediment cores were sampled using hand PVC cores (inner diameter $7.5 \mathrm{~cm}$ ) upto $60 \mathrm{~cm}$ from surface and used for chemical analyses. The sediment cores were sectioned into $10 \mathrm{~cm}$ thick segments and 30 $\mathrm{g}$ soil was immediately extracted in $75 \mathrm{ml}$ of $2 \mathrm{~mol} \mathrm{~L}^{-1}$ potassium chloride $(\mathrm{KCl})$. The mixture was shaken until well mixed and allowed to stand overnight. After $24 \mathrm{~h}, 4 \mathrm{~mL}$ of the supernatant was collected for the estimation of ammonia-nitrogen $\left(\mathrm{NH}_{4}\right.$

Figure 1. Map showing study site location.

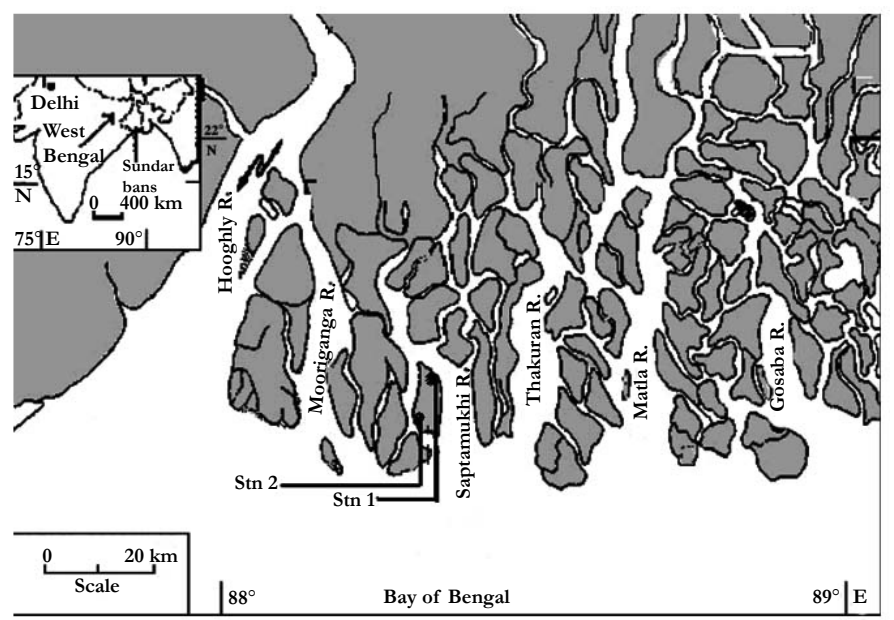


$+-\mathrm{N})$, nitrite $\left(\mathrm{NO}_{2}-\mathrm{N}\right)$, nitrate $\left(\mathrm{NO}_{3}-\mathrm{N}\right)$ nitrogen and phosphatephosphorus $\left(\mathrm{PO}_{4}{ }^{-3}-\mathrm{P}\right)$ by spectrophotometric method [45]. Sediment samples were placed in screw capped centrifuge tubes, from which pore water was separated avoiding air contact by means of centrifugation. Salinity of the pore water samples was determined by Mohr-Knudsen titration [48].

LEAF DNA, RNA, Chlorophyll And $C, N, P$ : The fully developed matured two leaf pairs per different mangrove tree were collected from an unshaded twig at $10 \mathrm{~m}$ height of the canopy and washed with Mili Q water. One pair was used for DNA and RNA estimation and other for chlorophyll as well as area. For DNA analysis, $10 \mathrm{~g}$ leaf sample without petioles were crushed in liquid nitrogen and homogenized in $50 \mathrm{ml}$ of extraction buffer containing $100 \mathrm{mM}$ Tris- $\mathrm{HCl}, 10 \mathrm{mM}$ EDTA, and $500 \mathrm{mM} \mathrm{NaCl}$, followed by the addition of $5 \mathrm{ml}$ SDS $(20 \%)$ with stirring for 15-20 min. The samples were incubated for $10 \mathrm{~min}$ at $65^{\circ} \mathrm{C}$. After mixing with $50 \mathrm{mM}$ ammonium acetate samples were incubated at $0^{\circ} \mathrm{C}$. The mixture was centrifuged to remove precipitate of protein [11] and the centrifugate was incubated at $-20^{\circ} \mathrm{C}$ for more than $1 \mathrm{~h}$ after mixing with isopropyl alcohol. The DNA precipitate was separated by centrifugation and washed with $70 \%$ ethyl alcohol. DNA was purified by phenolchloroform extraction and ethanol precipitation and was further purified by treatment with $\mathrm{LiCl}$ overnight at $0^{\circ} \mathrm{C}$ [46]. DNA was dissolved in saline citrate $(0.15 \mathrm{NaCl}, 0.015 \mathrm{M}$ tri-sodium citrate) buffer. The solution was treated with $6 \mathrm{ml}$ diphenylamine reagent (5g diphenylamine, $500 \mathrm{ml}$ glacial acetic acid and $13.7 \mathrm{ml}$ conc. $\mathrm{H}_{2} \mathrm{SO}_{4}$ ) and was incubated in water bath at $65^{\circ} \mathrm{C}$ for $10 \mathrm{~min}$. The mixture was cooled and DNA concentration in the mixture was measured spectrophotometrically using DNA standard procured from Sigma Chemical Company [8, 40].

For RNA analysis, $5 \mathrm{~g}$ sample was crushed in liquid nitrogen and were homogenized in extraction buffer $(0.1 \mathrm{M}$ Tris- $\mathrm{HCl}, 0.075 \mathrm{M}$ $\mathrm{NaCl}, 0.005 \mathrm{M}$ EDTA). The homogenate was centrifuged at 2000 $\mathrm{x} g$ for $3 \mathrm{~min}$. The supernatant was treated with $10 \% \mathrm{SDS}$ and buffered phenol (saturated pure phenol with $100 \mathrm{mM}$ Tris-HCl) and was extracted with chloroform. The process was repeated for 5 times. RNA was precipitated from the combined chloroform extract by adding ethyl alcohol containing $250 \mathrm{mg} \mathrm{NaCl}$ and incubating the mixture at $-20^{\circ} \mathrm{C}$ overnight. The residue was dissolved in $10 \mathrm{ml}$ ice-chilled buffer $(10 \mathrm{mM}$ Tris-acetate, $1 \mathrm{mM}$ EDTA) and was mixed with $6 \mathrm{ml}$ orcinol acid reagent (mixture of $2 \mathrm{ml} \mathrm{10 \%} \mathrm{ferric} \mathrm{chloride} \mathrm{solution} \mathrm{and} 400 \mathrm{ml}$ conc. $\mathrm{HCl}$ ). The mixture was treated with $0.4 \mathrm{ml}$ of $6 \%$ alcoholic orcinol and incubated in boiling water bath for $20 \mathrm{~min}$. RNA concentration in the mixture was determined spectrophotometrically using Baker's yeast RNA as standard $[4,12]$. Sensitivity of the methods used for DNA and RNA analysis was found to be $\pm 1.0 \mu \mathrm{g}$.

Leaf samples were collected from $10 \mathrm{~m}$ height of the mangrove plants and area of each leaf was measured. About $1 \mathrm{~g}$ of finely cut and well-mixed sample was extracted with $20 \mathrm{ml} 80 \%$ acetone and absorptions at $645,663 \mathrm{~nm}$ were measured for the estimation of total chlorophyll $(\mathrm{a}, \mathrm{b})$ using the relation: total chlorophyll $(\mathrm{a}, \mathrm{b}) / \mathrm{g}$ tissue $=20.2\left(\mathrm{~A}_{645}\right)+8.02\left(\mathrm{~A}_{663}\right) \times \mathrm{V} / 1000 \times \mathrm{W}$, where $\mathrm{A}$ is absorbance at specific wavelength, $\mathrm{V}$ is final volume of chlorophyll extract in $80 \%$ acetone, $\mathrm{W}$ is fresh weight of tissue extracted [53]. Leaf chlorophyll concentration is expressed in $\mu \mathrm{g}$ $\mathrm{cm}^{2}$. Carbon and nitrogen concentrations in the dried biomass were determined using a CHN Analyzer (2400 Series-11, Perkin
Elmer). The phosphorus concentration (\% mass) was determined after acidified persulfate digestion of finely ground leaves in autoclave followed by the measurement of orthophosphate by spectrophotometric methods [25]. The assay of protein involves extraction of fresh leaf samples frozen in liquid nitrogen in 0.1 $\mathrm{M} \mathrm{NaOH}$ and treatment of aliquot of centrifuged supernatant with Bradford reagent followed the measurement of absorbance at $595 \mathrm{~nm}[26]$.

Carbon Sequestration: Four common coexisting mangrove species: Avicennia alba, Avicennia marina, Aegialitis rotundifolia, Bruguiera gymnorrbiza were marked and measured for monthly increment of tree circumference at breast height (cbh), $1.3 \mathrm{~m}$. Diameter of breast height $(\mathrm{dbh}, \mathrm{cm})$ was calculated from $\mathrm{cbh}$. Monthly increment of above ground biomass was estimated from increased diameter (dbh) using allometric equations [34]. Results were expressed in terms of $\mu \mathrm{g} \mathrm{C} \mathrm{kg}{ }^{-1} \mathrm{AGB}$ month $^{-1}$ considering carbon concentrations of $42.09-42.5 \%$ in above ground biomass (AGB). For the estimation of net forest primary productivity both AGB and live below ground biomass (LBGB) are to be considered and Ray et al., 2011 [34] showed AGB to be about 4 times greater than LBGB in the Indian Sundarban mangrove forest.

\section{Statistical Analysis}

Statistical analyses were done by using MINITAB (version 13.1). Data obtained for different species were analysed for stepwise multiple regression analysis and ANOVA test. Significant contribution of parameters was taken into account in stepwise multiple regression analysis in order to avoid biasness in parameters selection [52].

\section{Results}

Salinity varied seasonally with a maximum of $30.0 \pm 1.29$ during the pre-monsoon and a minimum of $18.31 \pm 3.86$ during the monsoon. Down-core nutrient profiles exhibited an overall decreasing trend with depth. Extractable ammonium concentration at the surface of the sediment was about 3.32 $\pm 1.38 \mu \mathrm{g} \mathrm{g}^{-1}$, which steadily decreased to $2.64 \pm 1.24 \mu \mathrm{g} \mathrm{g} \mathrm{g}^{-1}$ at $60 \mathrm{~cm}$ depth. Similar to ammonium, surface nitrate and nitrite concentrations in the sediment decreased from $0.194 \pm 0.07 \mu \mathrm{g} \mathrm{g}^{-1}$ to $0.169 \pm 0.063 \mu \mathrm{g} \mathrm{g}^{-1}$ and from $0.039 \pm 0.022$ to $0.0385 \pm 0.025$ $\mu \mathrm{g} \mathrm{g}^{-1}$, respectively at $60 \mathrm{~cm}$ depth. However, mean ammonium concentration was found to be $92.5-95.2 \%$ of total inorganic nitrogen. In the sediment ammonium concentration was found about 21 times more abundant than nitrate. The similar pattern was observed in the pore-water, in which ammonium was about 1.9 fold more abundant than nitrate. Seasonal variation of mean inorganic nitrogen varied from $2.94 \mu \mathrm{g} \mathrm{g}^{-1}$ to $4.57 \mu \mathrm{g} \mathrm{g}^{-1}$ in the sediment, and from $4.72 \mu \mathrm{M}$ or $0.066 \mu \mathrm{g} \mathrm{g}^{-1}$ to $4.93 \mu \mathrm{M}$ or 0.069 $\mu \mathrm{g} \mathrm{g} \mathrm{g}^{-1}$ in pore water. Fluctuation of inorganic phosphate also showed lower concentration in pore water $(0.78 \mu \mathrm{M}$ or $0.024 \mu \mathrm{g}$ $\mathrm{g}^{-1}-1.62 \mu \mathrm{M}$ or $\left.0.05 \mu \mathrm{g} \mathrm{g}^{-1}\right)$ than that of sediment $\left(0.212 \mu \mathrm{g} \mathrm{g}^{-1}-\right.$ $\left.2.05 \mu \mathrm{g} \mathrm{g}^{-1}\right)$.

\section{Carbon sequestration}

Carbon sequestration rates were significantly higher in $A$. marina (5.19 $\left.\pm 0.29 \mathrm{~g} \mathrm{C} \mathrm{kg}^{-1} \mathrm{AGB} \mathrm{a}{ }^{-1}\right)$ and $A$. alba $\left(4.92 \pm 0.24 \mathrm{~g} \mathrm{C} \mathrm{kg}^{-1} \mathrm{AGB}\right.$ $\left.\mathrm{a}^{-1}\right)$ than those of $A$. rotundifolia $\left(3.63 \pm 0.40 \mathrm{~g} \mathrm{C} \mathrm{kg}^{-1} \mathrm{AGB} \mathrm{a} \mathrm{a}^{-1}\right)$ and 
B. gymnorrbiza (3.04 $\pm 0.37 \mathrm{~g} \mathrm{C} \mathrm{kg}^{-1} \mathrm{AGB} \mathrm{a}^{-1}$ ) (Figure 2, Table 1), and $A$. marina and $A$. alba also exhibited higher leaf-Chlorophyll content than those of $A$. rotundifolia and B. gymnorrbiza (Table 1).

\section{Leaf level RNA: DNA ratio, $\mathbf{N}$ and $\mathbf{P}$}

Leaf level RNA:DNA ratios showed significant seasonal variation (ANOVA, $\mathrm{p}<0.01$ ) and was found 10.6 for $A$. marina, 10.3 for A. alba, 7.9 for A. rotundifolia and 8.9 for B. gymnorrbiza (Figure 3). The RNA:DNA ratios of $A$. marina and $A$. alba were significantly higher than those of $A$. rotundifolia and B. gymnorrbiza
( $\mathrm{p}<0.05)$ and $A$. marina and $A$. alba also exhibited higher carbon sequestration than $A$. rotundifolia and B. gymnorrbiza. Interspecific differences in protein concentration is consistent with RNA and its concentrations in A. marina (150.46 $\left.\pm 10.17 \mathrm{mg} \mathrm{g}^{-1}\right)$ and $A$. alba $\left(150.09 \pm 12.62 \mathrm{mg} \mathrm{g}^{-1}\right)$ were found greater than in $A$. rotundifolia $\left(143.36 \pm 5.55 \mathrm{mg} \mathrm{g}^{-1}\right)$ and B. gymnorrbiza $\left(149.59 \pm 11.42 \mathrm{mg} \mathrm{g}^{-1}\right)$. The most interesting patterns were found to be the differences in $\mathrm{N}$ and $\mathrm{P}$ abundance among mangroves. Nitrogen was found more abundant in $A$. marina $(1.12 \%), A$. alba $(1.82 \%)$ than in $A$. rotundifolia $(0.13 \%)$, B. gymnorrbiza $(0.44 \%)$. Similar pattern was also observed for phosphorus with $0.134 \%$ for $A$. marina, $0.1 \%$ for $A$.

Figure 2. Monthly variation of carbon sequestration rate of Avicennia marina, Avicennia alba, Agealitis rotundifolia and Bruguiera gymnorhiza.

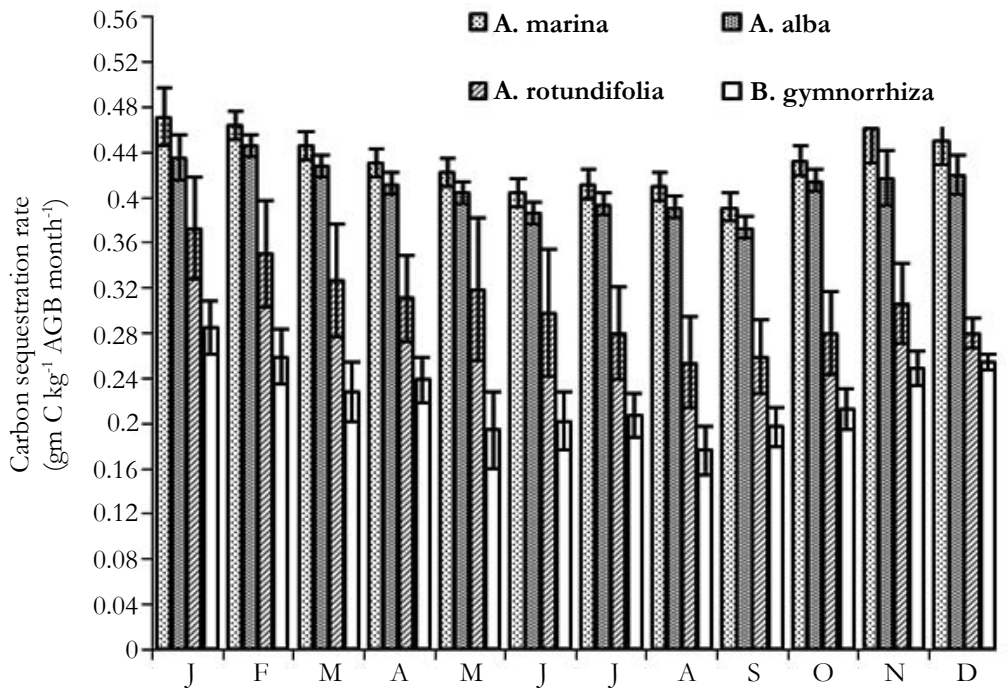

Table 1. Carbon, nitrogen, phosphorus, DNA, RNA, chlorophyll and potein contents in leaves of four mangrove species in Sandarban and Seasonal variation of salinity (S), different forms of inorganic nitrogen (N) and total inorganic phosphorus $(P)$ in sediments $\left(\mu \mathrm{g} \mathrm{g}^{-1}\right)$ and pore water $(\mu \mathrm{M})(\mathrm{n}=24)$.

\begin{tabular}{|c|c|c|c|c|}
\hline Species name & A. alba & A. marina & B. gymnorthiza & A. rotundifolia \\
\hline $\begin{array}{l}\text { Carbon sequestration rate } \\
\qquad\left(\mathrm{g} \mathrm{C} \mathrm{kg}^{-1} \mathrm{AGB} \mathrm{a} \mathrm{a}^{-1}\right)\end{array}$ & $4.92 \pm 0.24$ & $5.19 \pm 0.29$ & $3.04 \pm 0.37$ & $3.63 \pm 0.40$ \\
\hline $\mathrm{C}(\%)$ & $44.35 \pm 3.55$ & $43.05 \pm 3.21$ & $39 \pm 2.86$ & $40.17 \pm 2.65$ \\
\hline $\mathrm{N}(\%)$ & $1.82 \pm 0.45$ & $1.12 \pm 0.45$ & $0.44 \pm 0.22$ & $0.132 \pm 0.08$ \\
\hline $\mathrm{P}(\%)$ & $0.1 \pm 0.03$ & $0.134 \pm 0.02$ & $0.044 \pm 0.01$ & $0.027 \pm 0.02$ \\
\hline DNA $\left(\mu g g^{-1}\right)$ & $37.14 \pm 4.87$ & $39.52 \pm 5.45$ & $34.27 \pm 5.40$ & $31.045 \pm 4.80$ \\
\hline RNA $\left(\mu g g^{-1}\right)$ & $385.84 \pm 25.20$ & $419.26 \pm 31.65$ & $307.17 \pm 50.65$ & $246.10 \pm 26.91$ \\
\hline $\operatorname{chlorophyll}\left(\mu \mathrm{g} \mathrm{cm}^{-2}\right)$ & $59.67 \pm 5.25$ & $60.56 \pm 3.16$ & $55.59 \pm 4.01$ & $57.88 \pm 1.99$ \\
\hline Leaf Protein $\left(\mathrm{mg} \mathrm{g}^{-1}\right)$ & $150.09 \pm 12.62$ & $150.46 \pm 10.17$ & $149.59 \pm 11.42$ & $143.36 \pm 5.55$ \\
\hline Sediment & Premonsoon & Monsoon & \multicolumn{2}{|c|}{ Postmonsoon } \\
\hline $\mathrm{S}(\mathrm{PSU})$ & $30.0 \pm 2.53$ & $18.90 \pm 1.21$ & \multicolumn{2}{|c|}{$20.49 \pm 1.5$} \\
\hline NO2-N $(\mu g \mathrm{~g}-1)$ & $0.039 \pm 0.01$ & $0.051 \pm 0.03$ & \multicolumn{2}{|c|}{$0.023 \pm 0.01$} \\
\hline NO2-N $(\mu \mathrm{M})$ & $0.15 \pm 0.01$ & $0.32 \pm 0.02$ & \multicolumn{2}{|c|}{$0.08 \pm 0.01$} \\
\hline NO3-N $(\mu g g-1)$ & $0.180 \pm 0.01$ & $0.039 \pm 0.02$ & \multicolumn{2}{|c|}{$0.211 \pm 0.01$} \\
\hline NO3-N $(\mu \mathrm{M})$ & $1.86 \pm 1.09$ & $2.56 \pm 3.21$ & \multicolumn{2}{|c|}{$1.02 \pm 0.72$} \\
\hline NH4-N ( $\mu \mathrm{g} g-1)$ & $2.727 \pm 0.94$ & $1.788 \pm 0.56$ & \multicolumn{2}{|c|}{$4.338 \pm 0.81$} \\
\hline NH4-N $(\mu \mathrm{M})$ & $2.831 \pm 0.59$ & $2.053 \pm 1.67$ & \multicolumn{2}{|c|}{$3.620 \pm 1.14$} \\
\hline PO4 -P ( $\mu g g-1)$ & $0.338 \pm 0.12$ & $0.902 \pm 0.15$ & \multicolumn{2}{|c|}{$0.212 \pm 0.08$} \\
\hline PO4-P $(\mu \mathrm{M})$ & $1.05 \pm 0.28$ & $1.62 \pm 0.05$ & \multicolumn{2}{|c|}{$0.78 \pm 0.08$} \\
\hline
\end{tabular}


Figue 3. Monthly variation of RNA: DNA ratios in leaves of Avicennia marina, Avicennia alba, Agealitis rotundifolia and Bruguiera gymnorhiza.

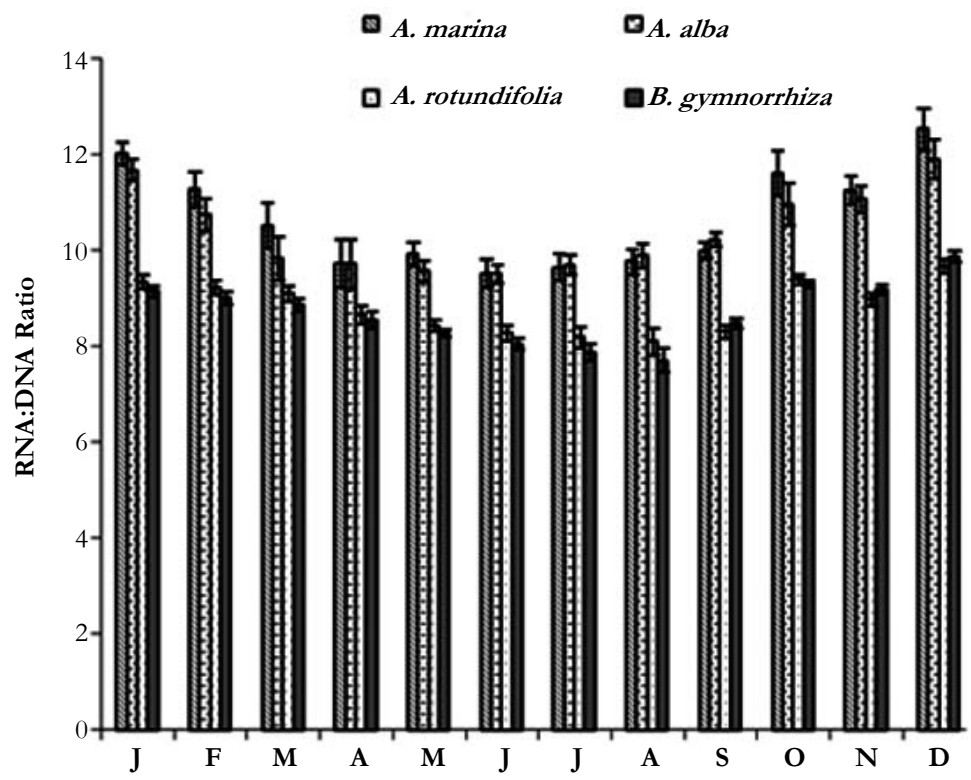

alba, $0.044 \%$ for B. gymnorrbiza and $0.027 \%$ for A. rotundifolia.

\section{Discussion}

The sediment in the study site was $\mathrm{N}$ poor $\left(3.75 \mu \mathrm{g} \mathrm{\textrm {g } ^ { - 1 }}\right)$, being lower than those of mean marine $\left(470 \mu \mathrm{g} \mathrm{g}^{-1}\right.$, Bowen, 1979) and other mangrove sediment (Australian, 4.3-7.3 $\mu \mathrm{g} \mathrm{g} \mathrm{g}^{-1}$, Boto and Welligton 1984). Interspecific and intraspecific differences in carbon sequestration were observed and this is consistent with the range of net photosynthesis rate observed for mangroves (from $22.0 \mu \mathrm{mol} \mathrm{CO} \mathrm{m}^{-2} \mathrm{~s}^{-1}$ in A. marina to $8.3 \mu \mathrm{mol} \mathrm{CO} \mathrm{m}^{-2} \mathrm{~s}^{-1}$ in B. gymnorrbiza) (Alongi 2009). Leaf-chlorophyll content obtained for four mangrove species in this study were with in the same range of values observed by Lee et al. 1990 [29] (42 $\pm 8 \mu \mathrm{g} \mathrm{cm}^{2}$ for shade adopted rain forest species and $56 \pm 11 \mu \mathrm{g} \mathrm{cm}{ }^{2}$ for sun adopted tropical forest species.

RNA: DNA ratios obtained for the Sundarban mangroves in this study were within the same range of values reported for Austalian mangroves i.e. 5.3-14.3 for Ceriops australis [43]. The significance of the response of the carbon sequestration rate was tested by multiple regression analysis (Table 2). The dependent variable is carbon sequestration rate and the independent variables are leaf level RNA: DNA, protein and soil parameters such as salinity (S), inorganic nitrogen $(\mathrm{N})$ and phosphate phosphorus $(\mathrm{P})$. Statistical analysis revealed significant correlation of carbon sequestration rate with independent variable tested $(p=0.003-0.044)$ and explained variability of carbon sequestration rate was found to be $47.4-57.3 \%$ for RNA:DNA, $6.2-25.3 \%$ for protein, 4.3$22.7 \%$ for $\mathrm{S}$ and $1.9-17.2 \%$ for $\mathrm{N}$ and $\mathrm{P}$ (Table 2). The coefficient of variation for RNA (23\%) was greater than DNA (8.6\%), indicating that RNA was directly involved in protein synthesis and therefore increases in RNA content were observed, whereas DNA content was relatively stable. Thus RNA:DNA ratio could be a good indicator of carbon sequestration in mangroves. Reef et al., 2010 [43] showed that RNA:DNA ratios could reliably predict growth rates on an interspecific level. The relationship between pore water salinity and carbon sequestration indicates that high salinity result to physiological responses, as highly saline soil has low osmotic potential that constrain water relation of mangroves [3]. Saintilan (1997) [47] also found substratum salinity as a major controlling factor for the variation of above ground biomass of A. marina and Aegiceras corniculatum.

\section{C: N: P ratio and nutrient conservation}

C: $\mathrm{P}$ molar ratios ranged between 834 and 1155 for $A$. marina, A. alba and between 2321 and 3719 for B. gymnorrbiza and $A$. rotundifolia. C: $\mathrm{N}$ ratio ranged between 18.6 and 40.6 for $A$. marina, A. alba, and between 103.5 and 356 for B. gymnorrbiza and $A$. rotundifolia (Table1). The mangrove leaf had molar C:N:P ratio of 834:18.6:1 for A. marina, 1155:40.6:1 for, $A$. alba, 2321:22.4:1 for B. gymnorrbiza and 3719:10.4:1 for $A$. rotundifolia: and the faster carbon sequestering species showed higher $\mathrm{N}$ and $\mathrm{P}$ content than the slower counterpart. A high carbon sequestration rate of $A$. marina and $A$. alba could be attributed to high demands of $\mathrm{N}$ and P. The range of $\mathrm{N}$ : P molar ratio was found to be $10.4-40.6$ (Table 1). Reef et al., (2010) [43] observed the variation of N: P from 39 to 51 in A. marina and from 19 to 79 in Ceriops austalis under $\mathrm{N}$ limited condition in a mixed scrub mangrove forest (1-2 m high), Moreton Bay, Queensland and good correlation was found between RNA : DNA ratios and growth rates for $A$. marina in contrast to C. austalis. Similarly, Naidoo (2009) [37], also reported that $\mathrm{N}$ could limit $A$. marina growth in South Africa. Elser et al., (2003, 2006) [17, 18], Bragg and Hyder (2004) [7], Acquisti et al., (2009) [1], suggested that $\mathrm{N}$ limitation could directly affect the RNA: DNA ratio. Mangroves could maintain high carbon sequestration through both phosphorus and nitrogen conservation followed by their additional allocation to ribosomes and protein synthesis (Growth Rate Hypothesis, [16, 19]).

\section{Conclusion}

The concentration of DNA, the biological molecule that contains the genetic information, varies within a relatively narrow range and is relatively insensitive to environmental factors such as nutrient availability and salinity stress. In contrast, a higher variation in RNA concentration indicates its direct implication in protein 
Table 2. Multiple regression analysis with stepwise variable selection. Dependent variable: Carbon sequestration rate (g C $\mathrm{kg}^{-1} \mathrm{AGB}$ month $\left.^{-1}\right)$, independent variables leaf level RNA: DNA, leaf Protein ( $\mathrm{mg} \mathrm{g}^{-1}$ ) Soil parameters: Salinity, (psu, S), N (nitrate, nitrite, ammonium $\left(\mu \mathrm{g} \mathrm{g}^{-1}\right), \mathbf{P}\left(\mu \mathrm{g} \mathrm{g^{-1 }}\right)$.

\begin{tabular}{|c|c|c|c|c|}
\hline Predictor & $\mathbf{R}^{2} \%$ & $\mathbf{P}$ & $\mathbf{N}$ & Regression equation \\
\hline \multicolumn{5}{|l|}{ A. marina } \\
\hline RNA:DNA & 57.3 & 0.018 & 12 & \multirow{5}{*}{$\begin{array}{c}\text { Carbon sequestration rate }=0.337+0.0122 \mathrm{RNA}: \mathrm{DNA} \\
-0.000749 \text { Protein }+0.00142 \text { Salinity }+0.00701 \mathrm{~N}+0.0530 \mathrm{P}\end{array}$} \\
\hline Protein & 63.5 & 0.028 & 12 & \\
\hline$S$ & 86.2 & 0.014 & 12 & \\
\hline $\mathrm{N}$ & 86.7 & 0.04 & 12 & \\
\hline $\mathrm{P}$ & 97.7 & 0.003 & 12 & \\
\hline \multicolumn{5}{|l|}{ A. alba } \\
\hline RNA:DNA & 50.7 & 0.031 & 12 & \multirow{5}{*}{$\begin{array}{c}\text { Carbon sequestration rate }=0.367-0.0163 \mathrm{RNA}: \mathrm{DNA}+0.00116 \\
\text { Protein }+0.00184 \text { Salinity }-0.0141 \mathrm{~N}+0.0653 \mathrm{P}\end{array}$} \\
\hline Protein & 75.7 & 0.014 & 12 & \\
\hline $\mathrm{S}$ & 80.0 & 0.026 & 12 & \\
\hline $\mathrm{N}$ & 84.5 & 0.044 & 12 & \\
\hline $\mathrm{P}$ & 95.9 & 0.027 & 12 & \\
\hline \multicolumn{5}{|c|}{ B. gymnorthiza } \\
\hline RNA:DNA & 52.0 & 0.028 & 12 & \multirow[t]{5}{*}{$\begin{array}{l}\text { Carbon sequestration rate }=-0.117-0.0192 \mathrm{RNA}: \mathrm{DNA}+ \\
0.00279 \text { Protein }+0.00210 \text { Salinity }+0.0117 \mathrm{~N}+0.0051 \mathrm{P}\end{array}$} \\
\hline Protein & 77.3 & 0.012 & 12 & \\
\hline$S$ & 91.7 & 0.004 & 12 & \\
\hline $\mathrm{N}$ & 93.5 & 0.012 & 12 & \\
\hline $\mathrm{P}$ & 93.6 & 0.042 & 12 & \\
\hline \multicolumn{5}{|c|}{ A. rotundifolia } \\
\hline RNA:DNA & 47.4 & 0.04 & 12 & \multirow{5}{*}{$\begin{array}{c}\text { Carbon sequestration rate }=0.331+0.0600 \text { RNA:DNA }-0.00507 \\
\text { Protein }+0.00312 \text { Salinity }+0.0608 \mathrm{~N}-0.0867 \mathrm{P}\end{array}$} \\
\hline Protein & 69.3 & 0.029 & 12 & \\
\hline $\mathrm{S}$ & 78.8 & 0.039 & 12 & \\
\hline $\mathrm{N}$ & 92.4 & 0.017 & 12 & \\
\hline $\mathrm{P}$ & 95.0 & 0.036 & 12 & \\
\hline
\end{tabular}

synthesis, which in turn is strongly dependent on environmental condition. Therefore, mangrove leaf level RNA:DNA ratio could reflect intraspecific and interspecific differences in carbon sequestration and they could maintain high carbon sequestration rate under nutrient limited condition through nutrient conservation strategies.

\section{Acknowledgement}

The authors gratefully acknowledge the support from the Department of science and technology, New Delhi. Thanks are also due to the Sundarban Biosphere Reserve and Divisional Forest Office, Government of West Bengal for giving permissions to bring required mangrove samples for the experiment. We thank the anonymous reviewers for their useful and constructive comments on the manuscript. This work was supported by the Department of Science and Technology (DST) (Sanction No. DST/IS-STAC/CO2-SR-42/08, dated 11.05.09), New Delhi, India.

\section{References}

[1]. Acquisti C., Kumar S, Elser JJ (2009) Signatures of nitrogen limitation in the elemental composition of the proteins involved in the metabolic apparatus. Royal Boi Sci 276(1667): 2605-2610.
[2]. Alongi DM (2009) The Energetics of Mangrove Forest. (1st edn), Springer Netherlands, Dordrecht. 11-24.

[3]. Ball MC (1996) Comparative ecophysiology of tropical lowland moist rain forest and mangrove forest.: Tropical Forest Plant Physiology. Springer US, New York. 461- 496

[4]. Benthin S., Nielsen J, Villadsen J (1991) A simple and reliable method for the determination of cellular RNA content. Biotechnol Tech 5(1): 39-42.

[5]. Boto KJ, Welligton JT (1984) Soil characteristics and nutrient status in a Northern Australian Mangrove forest. Estuaries 7(1): 61-69.

[6]. Bowen HJM. 1979. Environmental chemistry of the elements. London, UK: Academic Press.

[7]. Bragg JG, Hyder HC (2004) Nitrogen versus carbon use in prokaryotic genomes and proteomes. Proc R Soc 271: S374-S377.

[8]. Burton K (1956) A study of the conditions and mechanism of the diphenylamine reaction for the colorimetric estimation of DNA. Biochem J 62(2): 315-323.

[9]. Chen Y, Ye Y (2014) Effects of salinity and Nutrient addition on mangrove Excoecaria agallocha PLoS One 9 (4): e9337. doi:10.1371/journal.Pone: 0093337.

[10]. Christian G.D. 2001. Analytical Chemistry. $5^{\text {th }}$ edition. New York: John Wiley.

[11]. Deshmukh VP, Thakare PV, Chaudhar US (2007) A simple method for isolation of genomic DNA from fresh and dry leaves of Terminalia arjuna (Roxb.). Electron J Biotechnol 10(3): 468-472.

[12]. Devi A, Srivastava TI (1964) Estimation of pyridine nucleotides in a crude tissue extract, by colour reaction of nucleotide ribose with orcinol and ferric chloride. Anal Chem 36(4): 882-884.

[13]. Dortch Q, Roberts TL, Clayton JJR,. Ahmed SI (1983) RNA/DNA ratio and DNA concentrations as indicators of growth rate and biomass in planktonic marine organisms. Mar Ecol Progr Ser 13: 61-71.

[14]. Downton WJS (1982) Growth and osmotic relations of the mangrove Avi- 
cennia marina, as influenced by salinity. Australian J Plant Physiol 9(5): 519-528.

[15]. Lovelock CR, Feller IC, Ellis J, Schwars AM, Hancock N, et al., (2007) Mangove growth in New Zealand estuaries: the role of nutrient enrichment at sites with contrasting rates of sedimentation, Oecologia 153(3): 633-641.

[16]. Elser JJ, Dobberfuhl DR, Mackay NA, Champel SJH (1996) Organism size, life history and N: P stoichiometry. BioScience 46(9): 674-684.

[17]. Elser JJ, Acharya K, Kyle M, et al., (2003) Growth rate stoichiometry couplings in diverse biota. Ecol Lett 6(10): 936-943.

[18]. Elser JJ, Watts T, Bitler B, TA Markow (2006) Ontogenetic coupling of growth rate with RNA and P. Ecology 20(5): 846-856.

[19]. Elser JJ, Hamilton A (2007) Stoichiometry and the new biology: the future is now. PLOS Biology 5(7): e-181.

[20]. Evans JR (1989) Photosynthesis and nitrogen relationships in leaves of C3 plants. Oecologia 78(1): 9-19.

[21]. FAO (2004) Status and trends in mangrove area extent world wide. Forest Resources AssessmentProgramme.287.

[22]. Giri C, Ochieng E, Tieszen LL, Zhu Z, Singh A, et al., (2011) Status and distribution of mangrove forests of the world using earth observation satellite data. Glob Ecol Biogeogr 20(1): 154-159.

[23]. Gattuso P, Prakignoulle M, Wollast R (1998) Carbon and carbonate metabolism in coastal aquatic ecosystems. Annu Rev Ecol Evol Syst 29: 405-434.

[24]. Givnish T (1988) Adaptation to sun and shade: a whole-plant perspective. Australian J Plant Physiol 15(2): 63-92.

[25]. Grasshoff K, Ehrharft M, Kremling K (1983) Methods of Seawater Analysis. (2nd edn), Verlas Chemie, Germany. 125-187.

[26]. Jones CG, Hare JD, Compton SJ (1989) Measuring plant protein with Bradford Assay 1. Evaluation and standard method. J Chem Ecol 15(3): 979-992.

[27]. Kennell D. Magasanik B (1962) The relation of ribosome content to the rate of enzyme synthesis in Aerobacter aerogenes. Biochim et Biophys Acta 55(1-2): 139- 145 .

[28]. Lira-Medeiros CF, Parisod C, Fernandes RA, Mata CS, Cardoso MA, Paulo Cavalcanti GF (2010) Epigenetic Variation in Mangrove Plants Occurring in Contrasting Natural Environment. PLoS ONE 5(4): e10326. doi:10.1371/ journal.pone.0010326.

[29]. Lee WD, Bone AR, Tarsis SL., Storch D (1990) Correlation of leaf optical properties in tropical forest Sun and extremeshade plants. American J Bot 77 (3): 370-380.

[30]. López-Hoffman L, Anten NPR, Martínez-Ramos M., Ackerly DD (2007) Salinity and light interactively affect neotropical mangrove seedlings at the leaf and whole plant levels Oecologia 150(4): 545-556.

[31]. Lovelock CE, Feller IC, Mc Kee KL, Thompson R (2005) Variation in mangrove forest structure and sediment characteristics in Bolas del Toro, Panama. Caribbean J Sci 41(3): 456-464.

[32]. Lovelock CE, Feller IC, Ball MC, Ellis J, Sorrell B (2007) Testing the growth rate vs geochemical hypothesis for latitudinal variation in plant nutrients. Ecol Lett 10(12): 1154-1163.

[33]. Makino A, Sakashita H, Hidema J, Mae T, Ojima K, B Osmond (1992) Distinctive responses of ribulose-1,5-bisphosphate carboxylase and carbonic anhydrase in wheat leaves to nitrogen nutrition and their possible relationships to CO2-transfer resistance. Plant Physiol 100(4): 1737-1743.

[34]. Majumder N, Chowdhury C, Ray R, Jana TK (2011) DNA base composition heterogeneity in two Avicennia species in response to nitrogen limitation in the Sundarban mangrove forest, India. International J Biol Chem
5(4): 238-247. DOI:10.3923/ijbe.2011.238.247.

[35]. McKee KL (2012) Ecological functioning of mangroves under changing climatic conditions VLIZ Special Publication 57: 10-15.

[36]. Mukhopadhyay SK, Biswas H, De TK, Jana TK (2006) Fluxes of nutrients from the tropical river Hooghly at the landeocean boundary of Sundarbans, NE Coast of Bay of Bengal,India. Journal Mar Syst 62(1-2): 9-21.

[37]. Naidoo G (2009) Differential effects of nitrogen and phosphorus enirichment on growth of dwarf Avicennia marina mangroves. Aquat Bot 90(2): 184-190.

[38]. Niklas KJ, Owens T, Reich PB, Cobb ED (2005) Nitrogen/phosphorus leaf stoichiometry and the scaling of plant growth. Ecology Letters 8(6): 636642.

[39]. Noguchi K, Go CS, Miyazawa SI, Terashima I, Ueda S, Yoshinari T (2001) Costs of protein turnover and carbohydrate export in leaves of sun and shade species. Australian J Plant Physiol 28(1): 37-47.

[40]. Plumer DT (1971) An introduction to practical biochemistry. (3rd edn), Tata McGraw Hill Publication, India. 1(1): 14.

[41]. R. Ray, D. Ganguly, C. Chowdhury, M. Dey, S. Das, et al., (2011) Carbon sequestration and annual increase of carbon stock in a mangrove forest. Atmos Environ 45(28): 5016-5024.

[42]. Ray R, Chowdhury C, Majumder N et al., (2013) Improved model calculation of atmospheric $\mathrm{CO}_{2}$ increment in affecting carbon stock of tropical mangrove forest. Tellus B 65: 18981.

[43]. Reef R., Feller IC, Lovelock CE (2010) Nutrition of mangroves. Tree Physiology 30(9): 1148-1160.

[44]. Reef R., Ball MC, Feller IC, Lovelock CE (2010) Relationships among RNA;DNA ratio, growth and elemental stoichiometry in mangrove trees. Function Ecol 24(5): 1064-1072.

[45]. Riley RH, Peter M. Vitousek PM (1995) Nutrient dynamics and nitrogen trace gas flux during ecosystem development in montane rain forest. Ecology 76(1): 292-304. doi: 10.2307/1940650.

[46]. Sambrook J, Fritsch EF, Maniatis T (1989) Molecular Cloning: A laboratory manual. Cold Spring Laboratory Press, New York. 20(6): 285.

[47]. Saintilan N (1997) Above-and below-ground biomasses of two species of mangrove on the Hawkesbury River estuary, New South Wales. Marine \& Freshwater Research 48: 147-152.

[48]. Strickland JDH, Parsons TR (1972) A practical Handbook of Seawater Analysis. (2nd edn), Fisheries Research Board of Canada, Ottawa. 310.

[49]. Suzuki Y, Kihara-Doi T, Kawazu T, Miyake C. Makino A (2010) Differences in Rubisco content and its synthesis in leaves at different positions in Eucalyptus globulus seedlings. Plant Cell Environt 33(8): 1314-1323.

[50]. Twilley RR, Chem RH, Hargis T (1992) Carbon sinks in mangroves and their implications to carbon budget to tropical coastal ecosystem. Water Air Soil Pollut 64(1): 265-288.

[51]. Vrede T, Dobberfuhl DR, Kooijman S, Elser JJ (2004) Fundamental connection among organism C:N:P stoichiometry, macromolecular composition, and growth. Ecology 85(5): 1217-1229.

[52]. Whittingham MJ, Stephens PA, Bradbury RB, Freckleton RP (2006) Why do we still use stepwise modeling in ecology and behaviour? J Animal Ecol 75(5): 1182-1189.

[53]. Witham, FH, Blaydes DF, Devlin RM (1971) Experiments in Plant Physiology. Van Nostrand, New York. 245.

[54]. Yan L, Guizhu C (2007) Physiological adaptability of three mangrove species to salt stress. Acta Ecologica Sinica 27(6): 2208-2214. 